\title{
Infrastruktur Jalan, Belanja Modal dan Kesempatan Kerja: Bukti Data Panel Kabupaten Kota di Aceh
}

\author{
Muliadi $^{1}$, Khairul Amri ${ }^{2}$ \\ Fakultas Teknik, Universitas Syiah Kuala, Banda Aceh ${ }^{1}$ \\ Fakultas Ekonomi dan Bisnis Islam, Universitas Islam (UIN) Ar-Raniry, Banda Aceh ${ }^{2}$ \\ Correspondence email: muliadi.abi@unsyiah.ac.id, khairul.amri@ar-raniry.ac.id
}

\begin{abstract}
The main purpose of our research study is to investigate the effect of road infrastructure and capital spending on employment creation. Using a panel dataset of 23 districts/city in Aceh province from 2011 to 2018 fixed-effect methods of a panel regression model is utilized to analyze the data set. The study found that road infrastructure and capital spending have a positive and significant effect on employment creation. This thing indicates that the existence of the road infrastructure and capital spending have become the main determinant of employment creation in Aceh. Therefore, local government in Aceh has to increase the road infrastructure to improve the economic activity of the community and allocating local government budget for capital spending effectively.
\end{abstract}

Keywords : Capital Spending, Road Infrastructure, Employment, Panel Regression Model

\section{PENDAHULUAN}

Penciptaan lapangan kerja menjadi isu utama pembangunan ekonomi suatu wilayah (Amri dan Nazamuddin, 2018a).Terutama bagi wilayah dengan perkembangan jumlah angkatan kerja relatif cepat, pemerintah harus berupaya mengambil kebijakan pembangunan yang berorientasi pada penyerapan tenaga kerja.Kebijakan tersebut tentunya memperhatikan sektor ekonomi yang mampu menyerap tenaga kerja lebih banyak. Pada tahun 2000-an penyerapan tenaga kerja di Indonesia didominasi oleh sektor pertanian. Hal ini sangat beralasan karena lebih dari $60 \%$ penduduk Indonesia tinggal di daerah pedesaan dan memilih sektor pertanian sebagai pekerjaan utamanya. Seiring dengan perkembangan kegiatan ekonomi, kesempatan kerja di Aceh mengalami perubahan dari tahun ke tahun. Pada tahun 2011 jumlah angkatan kerja yang bekerja di daerah tersebut mencapai 1.852 .473 jiwa. Jumlah ini kemudian mengalami sedikit penurunan hingga menjadi 1.798.547 jiwa di tahun 2012.Penurunan ini mengindikasikan adanya sebagian tenaga kerja yang kehilangan pekerjaan sehingga mereka menganggur.Kemudian pada tahun 2013 jumlah kesempatan kerja di Aceh meningkat lagi hingga mencapai 1,824,586 jiwa.

Terjadinya fluktuasi kesempatan kerja di suatu daerah tentunya dapat dihubungkan dengan sejumlah faktor seperti tingkat upah dan pertumbuhan ekonomi (Amri, 2018), ketersediaan infrastruktur jalan (Ivanova \& Masarova, 2013) dan alokasi belanja pemerintah daerah dalam mendukung penciptaan lapangan kerja.Infrastruktur jalan menjadi faktor penentu mobilitas barang dan jasa dalam suatu perekonomian sehingga berdampak pada aktivitas ekonomi masyarakat di suatu daerah.Bahkan infrastruktur fisik tersebut dapat merangsang munculnya aktivitas ekonomi baru di masyarakat sehingga membuka lapangan pekerjaan dan menyerap sejumlah tenaga kerja (Amri, 2014).Adanya keterkaitan antara infrastruktur jalan dengan kesempatan sudah dibuktikan oleh sejumlah peneliti.Seperti halnya penelitian Asher \& Novosad (2010) di India yang menyimpulkan bahwa infrastruktur jalan dapat meningkatkan kesempatan kerja di daerah pedesaan. Sebelumnya, hasil kajian Fan et al. (2002) di China juga menyimpulkan bahwa pembangunan infrastruktur jalan mampu meningkatkan kesempatan kerja dan menurunkan angka kemiskinan pedesaan di negara tersebut. Alokasi anggaran pemerintah dalam bentuk belanja modal juga diharapkan mampu meningkatkan kesempatan kerja dan mendorong pertumbuhan ekonomi (Amri \& Aimon, 2017).Dalam konteks pemerintah daerah, belanja modal adalah belanja pemerintah daerah yang dimaksudkan untuk pembentukan modal atau aset tetap seperti pembangunan jalan, irigasi, pengadaan tanah serta dalam bentuk fisik lainnya (Amri, 2017b).Alokasi belanja modal oleh pemerintah di daerah tertentu diharapkan mampu menciptakan lapangan pekerjaan bagi masyarakat (Moudud, 1999).Hasil kajian Fouladi (2010) di Iran memberikan bukti empiris bahwa belanja modal dapat meningkatkan penyerapan tenaga kerja.

Selama periode 2011-2015 infrastruktur jalan di masing-masing kabupaten kota di Aceh sedikit mengalami peningkatan, baik dalam bentuk jalan nasional, provinsi maupun jalan kabupaten kota. Walaupun sebagian dari infrastruktur tersebut berada dalam kondisi rusak, namun peningkatan total panjang 
jalan mengindikasikan bahwa pembangunan infrastruktur jalan bagi peningkatan kegiatan ekonomi masyarakat terus dilakukan dari tahun ke tahun. Dalam periode waktu yang sama, realisasi belanja modal pemerintah kabupaten kota di Aceh relatif berbeda satu sama lain. Perbedaan tersebut tentunya tidak terlepas dari besarnya anggaran daerah yang diperuntukan dalam bentuk belanja modal. Selain itu, kemampuan pemerintah daerah dalam merealisasikan anggaran daerah yang berkaitan dengan belanja modal juga sangat menentukan realisasi anggaran tersebut. Kesempatan kerja di daerah kabupaten kota di Aceh juga relatif berbeda satu sama lain. Perbedaan teresbut tidak hanya terjadi antar kabupaten kota, akan tetapi juga terjadi pada kabupaten kota yang sama dalam periode tahun berbeda. Hingga tahun 2015, daerah dengan kesempatan kerja relatif besar adalah Aceh Utara, Aceh Besar dan Bireuen. Sebaliknya daerah dengan kesempatan kerja relatif kecil antara lain Aceh Jaya, Sabang dan Subulusalam. Perbedaan kesempatan kerja tersebut secara implisit mengindikasikan adanya perbedaan sejumlah faktor berpengaruh terhadap kesempatan kerja terutama jumlah angkatan kerja itu sendiri.

Sebagaimana dijelaskan sebelumnya, pembangunan infrastruktur jalan dan alokasi anggaran pemerintah daerah dalam bentuk belanja modal diharapkan mampu meningkatkan penyerapan tenaga kerja. Selama ini pemerintah kabupaten kota di Aceh sudah berupaya melakukan intervensi kebijakan yang berorientasi pada perbaikan infrastruktur fisik tersebut sehingga panjang jalan di Aceh meningkat dari tahun ke tahun. Selain itu, alokasi anggaran daerah untuk belanja modal juga mengalami peningkatan dengan tujuan dapat memberikan dampak positif bagi kegiatan ekonomi masyarakat.Bila penyerapan tenaga kerja dijadikan salah satu indikator keberhasilan kebijakan pembangunan infrastruktur jalan dan alokasi belanja modal, dipandang perlu menganalisis hubungan fungsional antara kedua variabel tersebut dengan kesempatan kerja. Namun, selama ini kajian empiris yang menganalisis pengaruh infrastruktur jalan dan belanja modal terhadap kesempatan kerja di Aceh belum banyak dilakukan para peneliti. Kalaupun ada, secara umum data yang mereka gunakan adalah data seri waktu (time series data). Guna mendapatkan hasil yang lebih baik dan informasi yang lebih akurat tentang keterkaitan antara variabel-variabel tersebut, penelitian kami menggunakan data panel seluruh kabupaten kota di Aceh.

\section{Literature Review}

\section{Keterkaitan Infrastruktur Jalan dan Kesempatan Kerja}

Kebijakan pembangunan yang dirumuskan oleh pemerintah daerah diharapkan berdampak pada perkembangan kegiatan ekonomi di daerah sehingga mampu meningkatkan pertumbuhan ekonomi dan mengurangi ketimpangan pendapatan masyarakat (Amri, 2017a; Amri \& Nazamuddin, 2018b).Ketersediaan infrastruktur jalan diharapkan berdampak positif terhadap mobilitas barang dan jasa yang pada gilirannya mampu meningkatkan kegiatan ekonomi masyarakat dan mendorong pertumbuhan ekonomi di daerah (Amri, 2014).Tidak hanya itu, ketersediaan infrastruktur tersebut juga dapat menciptakan lapangan kerja di daerah. Kajian mengenai keterkaitan antara infrastruktur jalan dengan kesempatan kerja telah banyak dilakukan oleh sejumlah peneliti. Seperti halnya kajian Kayode et al (2013) untuk kasus Nigeria, menemukan bahwa pembangunan infrastruktur transportasi terutama jalan raya mampu meningkatkan kesempatan kerja dan pembangunan ekonomi di negara tersebut. Hasil penelitian Padeiro (2013) di Perancis juga memberikan kesimpulan yang sama, dimana infrastruktur jalan juga dapat mendorong pertumbuhan kesempatan kerja. Demikian pula halnya dengan kajian Fageda \&Gonzalez-Aregall (2014) juga menyimpulkan adanya dampak positif infrastruktur transportasi terhadap kesempatan kerja. Adanya pengaruh infrastruktur jalan terhadap kesempatan kerja di suatu daerah juga diperkuat oleh hasil kajian Jiang et al. (2017) di China yang menyajikan bukti empiris bahwa pembangunan infrastruktur jalan yang menghubungkan antar daerah di negara tersebut mampu memberikan dampak signifikan pada peningkatan kesempatan kerja. Penelitian Johnson et al. (2017) dalam kasus Britania juga mengungkapkan bahwa jaringan transportasi publik berasosiasi positif dengan tingkat kesempatan kerja yang tinggi..

\section{Keterkaitan Belanja Modal dan Kesempatan Kerja}

Belanja atau pengeluaran pemerintah daerah tidak hanya dimaksudkan untuk memperlancar kegiatan operasional pemerintahan di daerah, tetapi melalui belanja daerah pemerintah dituntut untuk memperluas kesempatan kerja dan meningkatkan pertumbuhan ekonomi daerah (Amri, 2017b). Keberadaan belanja modal dalam anggaran daerah antara lain dimaksudkan untuk pembelian/pengadaan atau pembangunan asset 
tetap berwujud yang mempunyai manfaat lebih dari satu tahun, seperti peralatan dan mesin, gedung dan bangunan, jalan, irigasi dan jaringan, dan aset tetap lainnya. Tidak hanya itu, pengeluaran pemerintah daerah dalam bentuk belanja modal juga bersifat investasi sehingga diharapkan mampu meningkatkan kesempatan kerja (Amri dan Aimon, 2017). Adanya keterkaitan antara belanja modal dengan perluasan kesempatan kerja seperti dikemukakan oleh Moudud (1999) bahwa peningkatan belanja pemerintah terutama dalam bentuk belanja modal diharapkan mampu memperluas kesempatan kerja. Temuan penelitian Fouladi (2010) di Iran juga memberikan bukti empiris bahwa pengeluaran pemerintah dapat memperluas kesempatan kerja. Mengacu pada uraian di atas jelaslah bahwa belanja pemerintah dalam bentuk belanja modal dapat memperluas kesempatan kerja dan pada akhirnya mendorong pertumbuhan ekonomi di daerah. Semakin besar alokasi anggaran daerah dalam bentuk belanja modal semakin luas kesempatan kerja.

\section{METODE}

Dalam penelitian ini, predictor variable bagi kesempatan kerja dibatasi hanya pada infrastruktur jalan dan belanja modal. Data yang digunakan adalah data sekunder. Data tersebut berbentuk panel data terdiri dari data time series (runut waktu) selama periode tahun 2011-2018 ( $\mathrm{n}=8)$ dan data kerat silang (cross section data) yang diambil dari 23 kabupatenkota di Aceh. Data-data tersebut bersumber dari laporan BPS Aceh, BPS kabupatenkota di Aceh, BAPPEDA Aceh dan instansi terkait lainnya yang mempublikasikan data terkait. Variabel yang dioperasionalkan dalam penelitian ini terdiri dari kesempatan kerja, infrasktruktur jalan dan belanja modal. Kesempatan kerja yang dimaksudkan adalah jumlah angkatan kerja yang bekerja pada kabupaten kota dalam periode tahun tertentu dinyatakan dengan satuan orang. Selanjutnya, ketersediaan infrastruktur jalan diproksi dari total panjang jalan pada kabupaten kotadalam periode tahun tertentu terdiri dari jalan jalan provinsi dan jalan kabupaten/kota diukur dengan satuan kilometer. Terakhir, belanja modal adalah realisasi belanja modal pemerintah daerah kabupaten kota pada periode tahun tertentu dihitung dengan satuan ribu rupiah per kapita. Guna menganalisis pengaruh infrastruktur jalan dan belanja modal terhadap kesempatan kerja pada kabupaten kota di Aceh digunakan regresi linear berganda (multiple regresion). Karena data yang digunakan dalam penelitian ini adalah data panel yakni gabungan antara time series data dan cross-section data, maka regresi yang digunakan adalah regresi panel (Gujarati, 2006). Model regresi panel yang diaplikasikan untuk memprediksi kesempatan kerja dengan menggunakan dua predictor variable tersebut diformulasikan dalam persamaan (1).

$\mathrm{KK}_{\mathrm{it}}=\beta_{0}+\beta_{1} \mathrm{PJ}_{\mathrm{it}}+\beta_{2} \mathrm{BM}_{\mathrm{ij}}+e_{\mathrm{it}}$

Dimana: $\beta_{0}$ : Konstanta; $\mathrm{KK}_{\mathrm{it}}$ : Kesempatan kerja di kabupaten/kota i pada tahun $\mathrm{t} ; \mathrm{PJ}_{\mathrm{it}}$ : Panjang jalan di kabupaten/kota i pada tahun $\mathrm{t}$ (sebagai proksi dari infrastruktur jalan); $\mathrm{BM}_{\mathrm{it}}$ : Realisasi belanja modal di kabupaten/kota i pada tahun $\mathrm{t} ; \beta_{1}$ dan $\beta_{2}$ : Koefisien regresi $\mathrm{PJ}_{\mathrm{ij}}$ dan $\mathrm{BM}_{\mathrm{ij}}$; $\mathrm{i}$ : Kabupaten/kota; $\mathrm{t}$ : Tahun; $e$ : Error term

Mengingat masing-masing variabel memiliki pengukuran berbeda, maka data pada setiap variabel ditransformasikan ke dalam bentuk logaritma, sehingga persamaan 1 tersebut modifikasi menjadi persamaan (2).

$\operatorname{LogKK} K_{i t}=\beta_{0}+\beta_{1} \operatorname{LogPJ}_{i t}+\beta_{2} \operatorname{LogBM} M_{i t}+e_{\text {it }}$

Dimana: $\beta_{0}$ : Konstanta; $\operatorname{LogKK} K_{\text {it }}$ : Logaritma kesempatan kerja di kabupaten/kota i pada tahun $t$; $\operatorname{LogPJ} \mathrm{J}_{\text {it }}$ : Panjang jalan di kabupaten/kota i pada tahun $\mathrm{t}$ (sebagai proxy dari infrastruktur jalan); $\operatorname{LogBM}_{\mathrm{it}}$ : Realisasi belanja modal di kabupaten/kota i pada tahun $\mathrm{t} ; \beta_{1}$ dan $\beta_{2}$ : Koefisien regresi $\mathrm{PJ}_{\mathrm{it}}$ dan $\mathrm{BM}_{\mathrm{it}} ; \mathrm{i}$ : Kabupaten/kota; $\mathrm{t}$ : Tahun; $e$ :Error term

Regresi panel memiliki tiga pendekatan yaitu common effect model, fixed effect model dan random effect model. Untuk menentukan mana di antara tiga pendekatan tersebut yang dinilai paling akuratuntuk memprediksi pengaruh infrastruktur jalan dan belanja modal terhadap kesempatan kerja, digunakan Chow test dan Hausman test. Chow test digunakan untuk menentukan mana di antara dua metode (common effect model danfixed effect model) yang dinilai lebih baik. Sedangkan Hausman test digunakan untuk memutuskan apakah model regresi yang digunakan fixed effect atau random effect model.

\section{HASIL}

Sebagaimana dijelaskan sebelumnya, model analisis yang digunakan untuk menganalisis pengaruh infrastruktur jalan dan belanja modal terhadap kesempatan kerja adalah regresi panel. Hal ini disebabkan 
data yang digunakan merupakan data panel yakni gabungan antara dara time series selama periode tahun 2011-2018 dengan data cross section 23 kabupaten kota di Aceh. Penggunaan regresi panel menggunakan tiga pendekatan yakni common effect model, fixed effectmodel dan random effect model. Untuk menentukan mana di antara tiga pendekatan tersebut yang paling tepat digunakan dalam mengestimasi pengaruh infrastruktur jalan dan belanja modal terhadap kesempatan kerja, digunakan Chow test dan Hausman test. Chow test digunakan untuk memutuskan apakah menggunakan model common effect atau fixed effect, sedangkan Hausman test digunakan untuk memutuskan apakah menggunakan model fixed effect atau random effect. Selain itu, menggunakan sejumlah alat uji tersebut pemilihan salah satu model terbaik juga dapat dilakukan dengan melihat grafik residual yang dihasilkan dari masing-masing pendekatan.

Uji Chow test untuk menentukan apakah model yang dipilih common effect atau fixed effect didasarkan pada nilai $p$-value untuk cross-section $F$ dengan ketentuan jika $p$-value $>0,05$ maka model adalah common effect. Sebaliknya jika $p$-value< 0,05 maka model yang dipilih adalah fixed effect. Hasil uji Chow test ditunjukkan dalam Tabel 1.

Tabel 1

Hasil Chow Test

\begin{tabular}{llrrr}
\hline Uji Efek & & Statistic & df & \multicolumn{1}{c}{ p-value } \\
\hline Cross-Section Fixed Effects & Cross-section F & 189,716 & $(22,159)$ & 0,000 \\
& Cross-section Chi-square & 608,129 & 22 & 0,000 \\
\hline
\end{tabular}

Sumber: Data diolah

Berdasarkan Tabel 1 di atas dapat dilihat bahwa nilai $p$-value cross section $\mathrm{F}$ sebesar $0,000<0,05$. Dengan demikian dapat disimpulkan bahwa berdasarkan uji Chow test, model yang dipilih adalah fixed effect model. Selanjutnya uji Haussman test digunakan untuk menentukan apakah model yang dipilih fixed effect atau random effect. Pemilihan salah satu di antara kedua model tersebut didasarkan pada nilai $p$-value cross-section random dengan ketentuan jika nilai $p$-value $>0,05$ maka model yang dipilih adalah random effect. Sebaliknya jika nilai $p$-value $<0,05$ maka model yang dipilih adalah fixed effect. Hasil uji Haussman test seperti ditunjukkan dalam Tabel 2.

Tabel 2

Hasil Haussman Test

Cross-Section Random Effects

Uji Efek $\quad \mathbf{X}^{\mathbf{2}}$-Statistic

Sumber: Data diolah

Berdasarkan Tabel 2 dapat dilihat bahwa nilai $\mathrm{X}^{2}$-Statistik sebesar 49,626 dan nilai $p$-value sebesar 0,000. Nilai $X^{2}$-tabel pada tingkat keyakinan $95 \%$ pada $\mathrm{df}=2$ sebesar 5,991. Karena nilai $X^{2}$-Statistik $>X^{2}$ tabel $(49,626>5,991)$, dan nilai $p$-value $<0,05$ maka dapat disimpulkan bahwa fixed effect model lebih baik bila dibandingkan dengan random effect model. Sebelumnya hasil Chow test(tabel 1) juga mengindikasikan bahwa model terbaik juga fixed effect model.

Justifikasi statistik yang menyimpulkan bahwa fixed effect model dinilai lebih baik dibandingkan random effect model juga dapat didasarkan pada perbandingan grafik residual yang dihasilkan oleh kedua metode tersebut. Untuk lebih jelasnya dapat dilihat Grafik 1 dan 2.Keputusan tersebut juga sesuai dengan perbandingan residual yang dihasilkan oleh kedua pendekatan tersebut seperti ditunjukkan dalam Grafik 1 dan 2. 


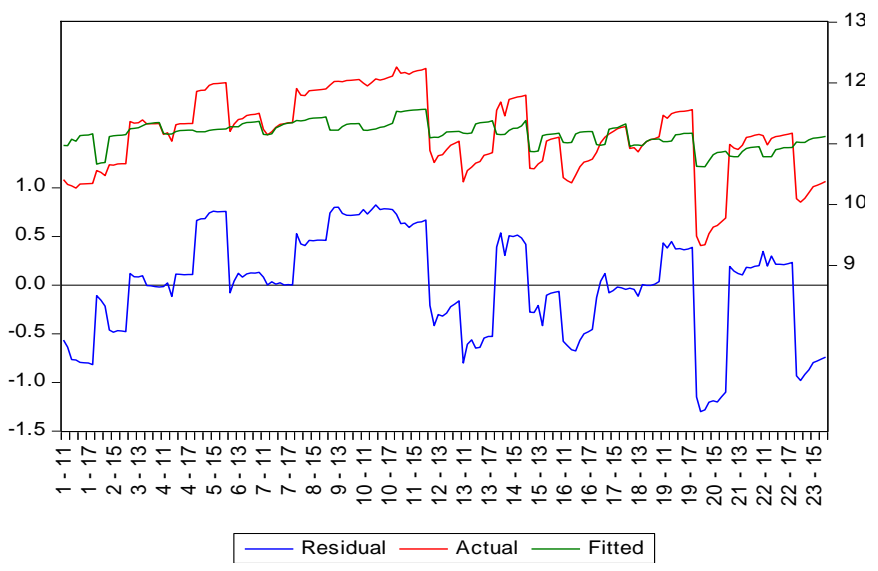

Grafik 1

Residual Metode Random Effect Model

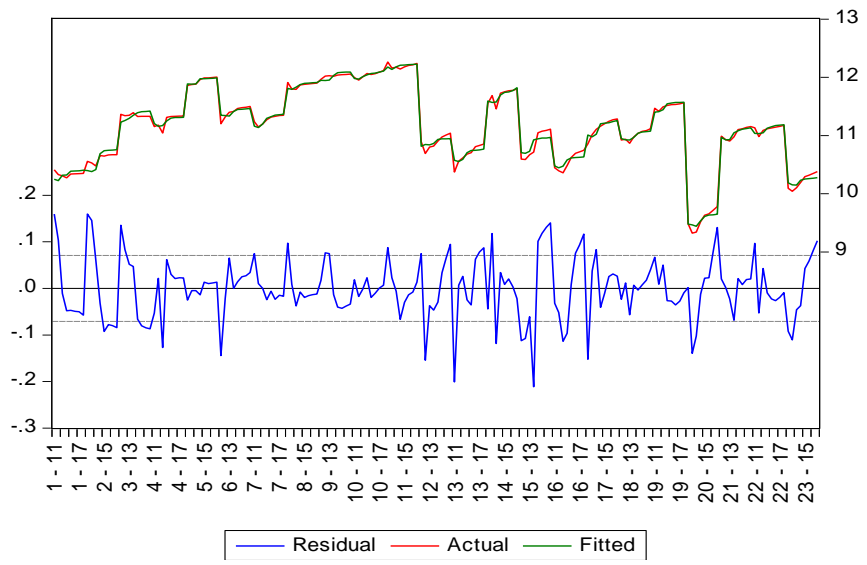

Grafik 2

Residual Metode Fixed Effect Model

Grafik 1 adalah grafik residual yang dihasilkan dari pendekatan random effect model. Pada grafik tersebut terlihat bahwa variasi/fluktuasi garis actual cenderung berbeda dengan fluktuasi garis fitted. Selanjutnya Grafik 2 memperlihatkan residual regresi panel yang dihasilkan oleh pendekatan fixed effect model. Pada grafik tersebut terlihat bahwa variasi/fluktuasi garis actual hampir sama dengan fluktuasi garis fitted. Berdasarkan perbandingkan garis actual dan garis fitted pada kedua grafik tersebut juga dapat disimpulkan bahwa pendekatan fixed effect model menghasilkan estimasi yang lebih akurat bila dibandingkan dengan pendekatan random effect model. Karena itu, regresi panel yang dipilih dan kemudian digunakan untuk kepentingan analisis dalam penelitian ini adalah fixed effect model.

\section{Uji Asumsi Klasik}

Ketepatan estimasi dengan menggunakan regresi panel sebagai alat analisis data tidak terlepas dari adanya asumsi klasik terutama asumsi normalitas residual dan asumsi multikolinieritas. Berdasarkan output eviews, estimasi pengaruh infrastruktur jalan dan belanja modal terhadap kesempatan kerja seperti dijelaskan di atas sudah memenuhi asumsi normalitas residual. Hal ini ditunjukkan oleh Grafik 3.

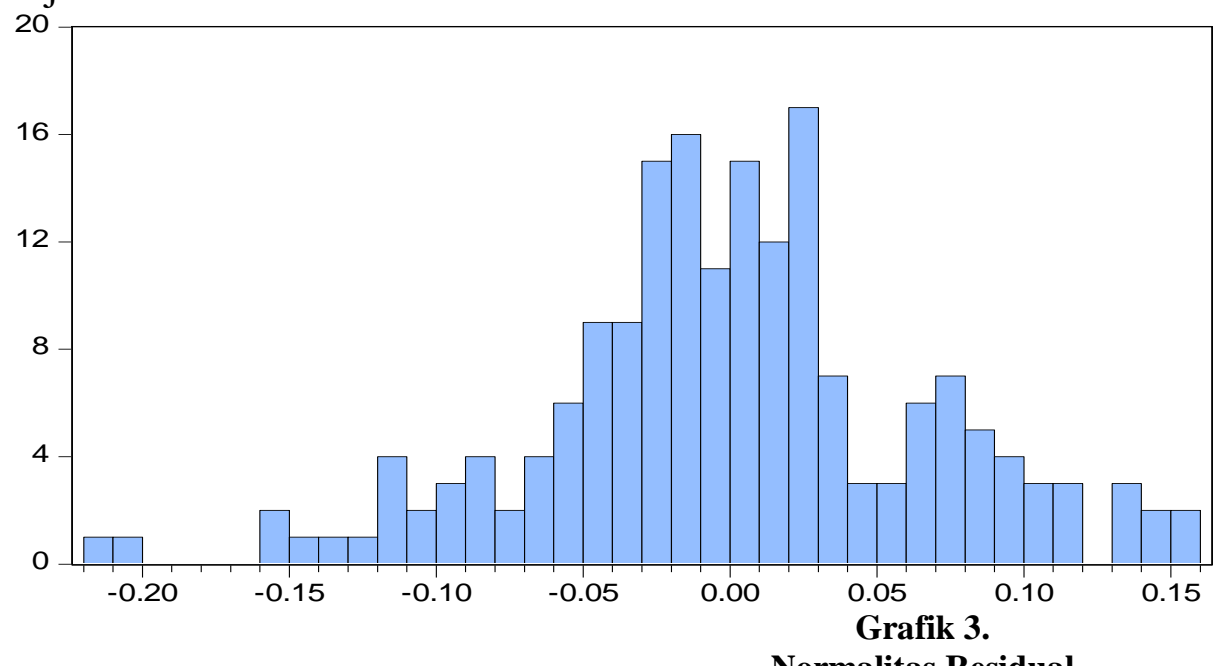

$\begin{array}{ll}\text { Series: Standardized Residuals } \\ \text { Sample 2011 } 2018 \\ \text { Observations } & 184 \\ & \\ \text { Mean } & -6.64 \mathrm{e}-18 \\ \text { Median } & -0.000936 \\ \text { Maximum } & 0.159688 \\ \text { Minimum } & -0.210908 \\ \text { Std. Dev. } & 0.065921 \\ \text { Skewness } & -0.162708 \\ \text { Kurtosis } & 3.581694 \\ & \\ \text { Jarque-Bera } & 3.406018 \\ \text { Probability } & 0.182135\end{array}$

Normalitas Residual

Grafik 3 di atas memperlihatkan nilai $J-B$ test sebesar 3,406 dengan prob sebesar 0,182(>0,05) dapat diartikan bahwa residual estimasi terdistribusi secara normal. Selanjutnya pengujian gejala multikolinieritas dalam model regresi panel dilakukan dengan membandingkan nilai Adjusted $R^{2}$ yang dihasilkan dariproses regresi dengan nilai koefisien korelasi ( $\mathrm{r}$ ) antara sesama variabel penjelas (predictor variable).Predictor variable dalam kajian ini adalah infrastruktur jalan dan belanja modal.Koefisien korelasi antar variabel seperti ditunjukkan dalam Tabel 3. 
Muliadi dan Khairul Amri, Infrastruktur Jalan, Belanja Modal dan Kesempatan Kerja: Bukti Data Panel Kabupaten Kota di Aceh

Tabel 3

Koefisien Korelasi antar Variabel

\begin{tabular}{lrrrr}
\hline \multicolumn{4}{c}{ LKK } & \multicolumn{3}{c}{ LBM } & LPJ \\
\hline LKK & & 1,0000 & & \\
LBM & & 0,729 & 1,0000 & \\
LPJ & 0,574 & 0,201 & 1,0000 \\
\hline
\end{tabular}

Sumber: Data diolah.

Tabel 3 menunjukkan nilai koefisien korelasi (r) antara infrastruktur jalan (LPJ) dengan belanja modal (LBM) sebesar 0,201. Angka ini lebih kecil dari nilai Adjusted- $R^{2}$ pada regresi panel sebesar 0,988. Hal ini berarti model regresi panel yang digunakan untuk memprediksi pengaruh infrastruktur jalan dan belanja modal terhadap kesempatan kerja tidak memiliki gejala multikolinieritas.

\section{Analisis Pengaruh Infrastruktur Jalan dan Belanja Modal terhadap Kesempatan Kerja}

Infrastruktur jalan dan belanja modal berpengaruh positif terhadap kesempatan kerja pada kabupaten kota di Aceh. Hal ini dapat dilihat dari nilai koefisien estimasi masing-masing variabel bernilai positif seperti ditunjukkan dalam rangkuman hasil regresi panel dalam Tabel 4.

Tabel 4

Hasil Estimasi Infrastruktur Jalan dan Belanja Modal terhadap Kesempatan Kerja

\begin{tabular}{lrrrrr}
\hline & Variable & Coefficient & Std. Error & t-Statistic & p-value \\
\hline C & 9,321 & 0,169 & 54,956 & 0.000 \\
LPJ & 0,195 & 0,034 & 5,778 & 0.000 \\
LBM & 0,077 & 0,014 & 5,543 & 0.000 \\
\hline
\end{tabular}

$\mathrm{R}^{2}=0,898 ;$ Adjusted-R ${ }^{2}=0,988 ;$ F-statistic $=640,272 ;$ Prob(F-test $)=0,000 ;$

Durbin-Watson test $=1,059$

Sumber: Data diolah

Berdasarkan Tabel 4 maka hubungan fungsional antara kesempatan kerja dengan infrastruktur jalan dan belanja modal pemerintah daerah kabupaten kota di Aceh dapat dinyatakan dalam persamaan (3). $\operatorname{LogKK}_{\mathrm{it}}=9,321+0,195 \operatorname{LogPJ} \mathrm{J}_{\mathrm{it}}+0,077 \operatorname{LogBM} \mathrm{ij}_{\mathrm{j}}$

Persamaan di atas mengindikasikan bahwa panjang jalan (PJ) sebagai proksi dari infrastruktur jalan berpengaruh positif dan signifikan terhadap kesempatan kerja dengan koefisien estimasi sebesar 0,195 ( $p$ value $=0,000<0,05)$. Peningkatan panjang jalan sebesar $1 \%$ dapat meningkatkan kesempatan kerja sebesar 0,195\% dengan asumsi belanja modal (BM) tidak mengalami perubahan.Hal ini mengindikasikan bahwa ketersediaan infrastruktur fisik tersebut merupakan faktor penentu penciptaan lapangan kerja di Aceh. Daerah dengan ketersediaan infrastruktur jalan lebih panjang (lebih memadai) akan memiliki kesempatan kerja relatif lebih besar dibandingkan dengan daerah dengan infrastruktur jalan kurang memadai. Dengan kata lain, semakin baik ketersediaan infrastruktur tersebut, semakin besar kesempatan kerja. Sehingga terdapat hubungan searah antara kedua variabel tersebut.Temuan ini konsisten dengan hasil kajian Kwon (2000) dan Fan et al. (2002) yang juga menyimpulkan adanya dampak positif infrastruktur jalan terhadap penciptaan lapangan kerja. Hasil kajian Asher \& Novosad (2010) juga memberikan kesimpulan yang sama yakni peningkatan jaringan jalan tidak hanya mempermudah mobilitas barang dan jasa di masyarakat, tetapi juga berdampak pada peningkatan kesempatan kerja.

Selanjutnya, belanja modal (BM) juga berpengaruh positif dan signifikan terhadap kesempatan kerja. Hal ini ditunjukkan oleh koefisien estimasi sebesar 0,077 ( $p$-value $=0,000<0,05)$. Secara statistik, angka tersebut dapat diinterpretasikan bahwa setiap peningkatan alokasi belanja pemerintah kabupaten kota di Aceh sebesar 1\% mendorong peningkatan kesempatan kerja sebesar 0,077\% dengan asumsi panjang jalan tidak berubah. Kabupaten kota yang mengalokasikan anggaran daerahnya dalam bentuk belanja modal dalam porsi relatif lebih besar, akan cenderung memiliki kesempatan kerja yang juga relatif lebih besar dibandingkan daerah dengan belanja modal relatif lebih kecil. Demikian pula sebaliknya, daerah dengan belanja modal relatif lebih kecil, peningkatan lapangan kerja di daerah tersebut juga relatif lebih sedikit dibandingkan daerah dengan alokasi belanja modal relatif lebih besar.Hal ini sesuai pendapat Moudud (1999) bahwa alokasi belanja modal oleh pemerintah tidak hanya berorientasi pada penyediaan infrastruktur 
publik bagi masyarakat, tetapi juga diharapkan mampu menciptakan lapangan kerja dan mengurangi angka pengangguran. Temuan penelitian ini mendukung hasil penelitian Fouladi (2010) di Iran yang juga membuktikan adanya pengaruh positif dan signifikan belanja pemerintah terhadap peningkatan kesempatan kerja.

\section{SIMPULAN}

Perkembangan kesempatan kerja di daerah kabupaten kota di Aceh secara signifikan dipengaruhi oleh ketersediaan infrastruktur jalan dan belanja modal pemerintah daerah. Hal ini mengindikasikan bahwa aktivitas ekonomi masyarakat di daerah tersebut sangat tergantung pada ketersediaan infrastruktur jalan dan alokasi anggaran daerah untuk penyediaan barang-barang modal. Daerah dengan infrastruktur jalan lebih memadai sehingga mampu meningkatkan mobilitas barang dan jasa serta penduduk antar kawasan di daerah tersebut, akan memiliki kesempatan kerja yang lebih besar dibandingkan daerah lain dengan infrastruktur jalan kurang memadai. Demikian pula halnya dengan alokasi anggaran belanja modal, daerah dengan porsi belanja modal relatif lebih besar mampu menyediakan lapangan kerja yang juga relatif lebih besar dibandingkan daerah dengan belanja modal relatif lebih kecil.

Mengacu pada kesimpulan tersebut, maka saran dan rekomendasi penelitian ini sebagai berikut.

1. Pemerintah pusat, provinsi dan pemerintah kabupaten kota di Aceh harus memberikan perhatian serius terhadap pembangunan infrastruktur jalan di seluruh kabupaten kota di daerah tersebut. Hal ini disebabkan tanggung jawab pembangunan infrastruktur jalan untuk mendorong kegiatan ekonomi masyarakat bukan hanya tanggung jawab pemerintah kabupaten kota, tetapi juga pemerintah pusat dan pemerintah provinsi. Pembangunan infrastruktur jalan terutama di kawasan pedesaan akan dapat membuka kesempatan kerja baru terutama kesempatan kerja di sektor pertanian. Apalagi mayoritas masyarakat kabupaten kota di Aceh bekerja di sektor pertanian.

2. Pemerintah kabupaten kota di Aceh perlu meningkatkan alokasi anggaran daerah dalam bentuk belanja modal. Simulasi kebijakan berkaitan dengan dampak belanja modal dalam penyediaan infrastruktur fisik tertentu terhadap perluasan kesempatan kerja sangat diperlukan untuk menentukan mana di antara berbagai alternatif pilihan alokasi belanja modal yang dinilai lebih efektif untuk meningkatkan kesempatan kerja di daerah. Selain itu, perencanaan dan pengelolaan belanja modal harus mengacu pada prinsip efisiensi dan efektivitas penggunaan anggaran tersebut guna meningkatkan kegiatan ekonomi dan penyediaan lapangan kerja bagi masyarakat.

\section{DAFTAR PUSTAKA}

Amri, K. 2014. Infrastruktur Transportasi dan Kepadatan Penduduk Dampaknya Terhadap Pendapatan Per Kapita: Panel Data Evidence dari Sembilan Provinsi di Sumatera, Jurnal Ekonomi Manajemen dan Bisnis, 2 (2), 438-450

Amri, K. 2017a. Analisis Pertumbuhan Ekonomi dan Ketimpangan Pendapatan: Panel Data 8 Provinsi di Sumatera, Jurnal Ekonomidan Manajemen Teknologi, 1(1), 1-11

Amri, K. 2017b. Indek Harga Konsumen dan Belanja Modal Terhadap Indek Perilaku Korupsi, SI-MEN (Akuntansi dan Manajemen) 8(1), 49-65.

Amri, K. 2018. The macroeconomic impact of regional minimum wages: A cross-province data evidence from Indonesia, Regional Science Inquiry, 10(3), 163-176.

Amri, K., \& Aimon, H. 2017. Pengaruh Pembentukan Modal Dan Ekspor Terhadap Pertumbuhan Ekonomi Indonesia, Economac 1(1), 1-16.

Amri, K., \& Nazamuddin. 2018a. Is There Causality Relationship between Export and Employment: A Time Series Data Evidence from Indonesia. International Journal of Academic Research in Economics and Management Sciences, 7(2), 86-99.

Amri, K., \& Nazamuddin. 2018b. Is there causality relationship between economic growth and income inequality? Panel data evidence from Indonesia, Eurasian Journal of Economics and Finance, 6(2), 8-20.

Asher, S.,\& Novosad, P. 2010. The Employment Effects of Road Construction in Rural India.

Fageda, X., \& Gonzalez-Aregall, M. 2014. The Spatial effects of transportation on industrial employment, Research Institute of Applied Economics Working Paper 2014/29 1/26 
Fan, S., Zhang, L.X.,\& Zhang, X. B. 2002. Growth, Inequality, and Poverty in Rural China: The Role of Public Investments. Research Report, International Food Policy Research Institute, Washington, D.C.

Fouladi, M. 2010. The Impact of Government Expenditure on GDP, Employment and Private Investment a CGE Model Approach, Iranian Economic Review, 15(27), 53-76.

Gujarati, D. 2006. Ekonometrika Dasar. Alih Bahasa: Sumarno Zain, Erlangga: Jakarta.

Ivanova, E., \& Masarova, J. 2013.Importance of road infrastructure in the economic development and competitiveness, Economics and Management, 18(2), 263-274.

Jiang, X., He, X., Zhang, L., Qina, H., \& Shao, F. 2017.Multimodal transportation infrastructure investment and regional economic development: A structural equation modeling empirical analysis in China from 1986 to 2011, Transport Policy 54, 43-52.

Johnson, D., Ercolani, M., \& Mackie, P. 2017. Econometric analysis of the link between public transport accessibility and employment, Transport Policy 60, 1-9.

Kayode, O., Babatunde, O. A., \& Abiodun, F. 2013. An empirical analysis of transport infrastructure investment and economic growth in Nigeria, Social Sciences,2(6): 179-188

Kwon, E. K. 2000. Infrastructure, Growth, and Poverty Reduction in Indonesia: A Cross-sectional Analysis. Asian Development Bank, Manila.

Moudud, J. K. 1999. Government Spending in a Growing Economy, Public Policy Brief, No. 52.

Padeiro, M. 2013. Transport infrastructures and employment growth in the Paris metropolitan margins, Journal of Transport Geography 31, 44-53.

Sulistyowati, N. 2013. The Effect of Educational, Healt, Infrastructure Expenses on the Workforce Employement and Poverty, International Journal of Administrative Science \& Organization, 20(3), 121-128. 